\title{
The Relationship Between Prognostic and Organ Failure Scoring Systems Such as APACHE II, SAPS II, MODS, SOFA and GCS and Quantitative Amino Acid Levels in Intensive Care Unit Patients
}

\author{
Yoğun Bakım Ünitesindeki Hastalarda APACHE II, SAPS II, MODS, SOFA \\ ve GKS gibi Prognostik ve Organ Yetmezliği Skorlama Sistemleri ile Serum \\ Amino Asit Düzeyleri Arasındaki İlişki
}

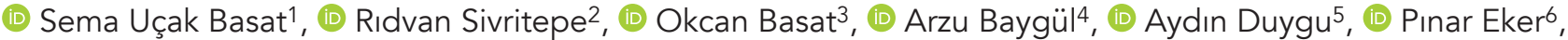 \\ (D) Kamil Özdil7 \\ ${ }^{1}$ University of Health Sciences Turkey, Ümraniye Training and Research Hospital, Clinic of Internal Medicine, Istanbul, Turkey \\ ${ }^{2}$ Istanbul Medipol University Faculty of Medicine, Department of Internal Medicine, Istanbul, Turkey \\ ${ }^{3}$ University of Health Sciences Turkey, Gaziosmanpaşa Taksim Training and Research Hospital, Clinic of Family Medicine, Istanbul, Turkey \\ ${ }^{4}$ Koç University Faculty of Medicine, Department of Biostatistics, Istanbul, Turkey \\ ${ }^{5}$ Amino Acid Science Ltd, Translation and Innovation Hub, London \\ ${ }^{6}$ Maltepe University Faculty of Medicine, Laboratory Director, Istanbul, Turkey \\ ${ }^{7}$ University of Health Sciences Turkey, Ümraniye Training and Research Hospital, Clinic of Gastroenterology, Istanbul, Turkey
}

\begin{abstract}
Objective: This study aimed to investigate the relationship between the prognostic and organ failure scoring systems and quantitative amino acid levels in patients in the intensive care unit (ICU).

Methods: A total of 45 patients over 45 years old, who were admitted to the ICU, were included in the study. Physical examinations of all patients were performed, and blood tests (including serum amino acids) were analyzed. Sequential organ failure assessment (SOFA), multiple organ dysfunction score (MODS), simplified acute physiology score II (SAPS II), acute physiology and chronic health evaluation II (APACHE II), and glasgow coma scale (GCS) scores of patients were calculated. Risk ratios were determined according to the mortality and organ failure scores of patients, and patients were grouped as high-risk and low risk. All these parameters were compared between these groups, and the relationship between amino acid levels and risk scores was evaluated. Statistical significance level was determined as a $p$-value of $<0.05$.

Results: This study was carried out on 45 patients, 23 females and 22 males. The mean age of the patients was $74 \pm 11$ years. In high-risk patients compared to low-risk group; methionine, ornithine, and phenylalanine levels according to APACHE II; beta-alanine, cystine, 3-methyl histidine, phenylalanine, and proline levels according to SAPS II; alanine, beta-alanine, phenylalanine, glycine, histidine, methionine, and ornithine levels according to GCS were significant different ( $p<0.05$ for all). We found a significant positive correlation between the APACHE II score and beta alanine ( $r=0.466 ; p=0.001)$, citrulline $(r=0.394 ; p=0.007)$, ethanolamine $(r=0.366 ; p=0.013)$, histidine $(r=0.353 ; p=0.017), 3$-methyl histidine $(r=0.450 ; p=0.002)$, ornithine $(r=0.445 ; p=0.002)$, phenylalanine $(r=0.548 ; p<0.001)$. There was a significant positive correlation between the SAPS II score and beta alanine $(r=0.403 ; p=0.006)$, cystathionine $(r=0.341 ; p=0.022)$, ethanolamine $(r=0.356 ; p=0.017), 3$-methyl histidine $(r=0.402$; $p=0.006)$, ornithine $(r=0.349 ; p=0.019)$, phenylalanine $(r=0.525 ; p<0.001)$ and between the MODS score and alanine $(r=0.340 ; p=0.022)$, beta alanine $(r=0.407 ; p=0.006)$, cystathionine $(r=0.352 ; p=0.018)$, ethanolamine $(r=0.358 ; p=0.0169)$, histidine $(r=0.495 ; p=0.001), 3$-methyl histidine $(r=0.407 ; p=0.006)$, methionine $(r=0.462 ; p=0.001)$, ornithine $(r=0.360 ; p=0.015)$, phenylalanine $(r=0.621 ; p<0.001), p r o l i n e(r=0.445 ; p=0.002)$. We found a significant positive correlation between the SOFA score and alanine ( $r=0.547 ; p<0.0019)$, beta-alanine $(r=0.354 ; p=0.0179)$, arginine $(r=0.423 ; p=0.004)$, cystathionine $(r=0.423 ; p=0.004)$, ethanolamine $(r=0.437 ; p=0.003)$, glycine $(r=0.399 ; p=0.007)$, histidine $(r=0.512 ; p<0.001)$, 3-methyl histidine $(r=0.327 ; p=0.028)$, leucine $(r=0.376 ; p=0.011)$, methionine $(r=0.585 ; p<0.001)$, ornithine $(r=0.467 ; p=0.001)$, phenylalanine
\end{abstract}

Address for Correspondence: Rıdvan Sivritepe, Istanbul Medipol University Faculty of Medicine, Department of Internal Medicine, Istanbul, Turkey

Phone: +905452605957 E-mail: dr.ridvansivritepe@gmail.com ORCID ID: orcid.org/0000-0003-0547-1883

Cite as: Uçak Basat S, Sivritepe R, Basat O, Baygül A, Duygu A, Eker P, Özdil K. The Relationship Between Prognostic and Organ Failure Scoring Systems Such as APACHE II, SAPS II, MODS, SOFA and GCS and Quantitative Amino Acid Levels in Intensive Care Unit Patients.

Received: 16.07.2021 Med J Bakirkoy 2021;17:334-342

Accepted: 01.10.2021 
$(r=0.644 ; p<0.001)$, proline $(r=0.523 ; p<0.001)$, threonine $(r=0.371 ; p=0.012)$. Also, there was a significant negative correlation between $G C S$ score and beta alanine $(r=-0.390 ; p=0.008)$, ethanolamine $(r=-0.364 ; p=0.014)$, glycine $(r=-0.360 ; p=0.015)$, ornithine $(r=-0.510 ; p=0.000)$, phenylalanine ( $r=-0.433 ; p=0.003)$.

Conclusion: This study found significantly higher methionine, ornithine, phenylalanine, beta-alanine, cystine, 3-methyl histidine, proline, alanine, glycine, and histidine levels in patients with high-risk scores.

Keywords: Amino acids, intensive care units, prognosis, risk factors, APACHE, simplified acute physiology score, organ dysfunction scores

\section{öz}

Amaç: Bu çalışmada yoğun bakım ünitesindeki (YBÜ) hastalarda prognostik ve organ yetmezliği skorlama sistemleri ile serum aminoasit düzeyleri arasındaki ilişki araştıııldı.

Gereç ve Yöntem: Çalışmaya 45 yaş üstü herhangi bir nedenden dolayı dahiliye YBÜ'ye interne edilen 45 hasta dahil edildi. Tüm hastaların fizik muayeneleri yapıldı ve kan tetkikleri (kantitatif amino asitler dahil) analiz edildi. Hastaların sıralı organ yetmezliği değerlendirmesi (SOFA), çoklu organ disfonksiyon skoru (MODS), Basitleştirilmiş akut fizyoloji skoru II (SAPS II), akut fizyoloji ve kronik sağlık değerlendirmesi II (APACHE II), ve glasgow koma skalası (GCS) skorları hesaplandı. Kantitatif aminoasit düzeyleri ölçüldü. Hastaların mortalite ve organ yetmezliği skorlarına göre risk oranları belirlendi ve hastalar yüksek riskli ve düşük riskli olarak gruplandırıldı. Tüm parametreler bu gruplar arasında karşılaştıııldı ve amino asit seviyeleri ile risk skorları arasındaki ilişki değerlendirildi. İstatistiksel analizde $p<0,05$ kabul edildi.

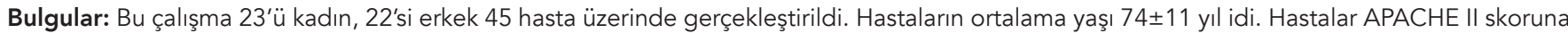
göre düşük riskli ( $<25$ puan) ve yüksek riskli ( $\geq 25$ puan) diye iki gruba ayrıldığında metiyonin $(p=0,011)$, ornitin $(p=0,019)$ ve fenilalanin $(p<0,001)$; SAPS II skoruna göre düşük riskli ( $\leq 40$ puan) ve yüksek riskli ( $>40$ puan) diye iki gruba ayrıldığında beta-alanin $(p=0,038)$, sistin $(p=0,038), 3-m e t i l$ histidin ( $p=0,024)$, fenilalanin $(p=0,011)$ ve prolin $(p=0,027)$; GKS skoruna göre yüksek riskli ( $\leq 8$ puan), orta riskli (8-13 puan) ve düşük riskli $(\geq 13$ puan) diye üç gruba ayrıldığında alanin $(p=0,031)$, beta-alanin $(p=0,035)$, fenilalanin $(p=0,006)$, glisin $(p=0,005)$, histidin $(p=0,007)$, metiyonin $(p=0,044)$ ve ornitin $(p=0,007)$ düzeyleri arasında anlamlı farklılık saptandı. APACHE II skoru ile beta alanin $(r=0,466 ; p=0,001)$, sitrulin $(r=0,394$; $p=0,007)$, etanolamin $(r=0,366 ; p=0,013)$, histidin $(r=0,353 ; p=0,017)$, 3-metil histidin $(r=0,450 ; p=0,002)$, ornitin $(r=0,445 ; p=0,002)$, fenilalanin $(r=0,548 ; p<0,001)$ arasında pozitif yönlü orta düzeyde; SAPS II skoru ile beta alanin $(r=0,403 ; p=0,006)$, sistatyonin $(r=0,341 ; p=0,022)$, etanolamin $(r=0,356 ; p=0,017)$, 3-metil histidin $(r=0,402 ; p=0,006)$, ornitin $(r=0,349 ; p=0,019)$, fenilalanin $(r=0,525 ; p<0,001)$ arasında pozitif yönlü orta düzeyde, glisin, valin arasında pozitif yönlü zayıf düzeyde; MODS skoru ile alanin ( $r=0,340 ; p=0,022)$, beta alanin $(r=0,407 ; p=0,006)$, sistatyonin $(r=0,352 ; p=0,018)$, etanolamin $(r=0,358 ; p=0,0169)$, histidin $(r=0.495 ; p=0,001)$, 3-metil histidin $(r=0,407 ; p=0,006)$, metiyonin $(r=0,462$; $p=0,001)$, ornitin $(r=0,360 ; p=0,015)$, fenilalanin $(r=0,621 ; p<0,001)$, prolin $(r=0,445 ; p=0,002)$ arasında pozitif yönlü orta düzeyde; SOFA skoru ile alanin ( $r=0,547 ; p<0,0019)$, beta-alanin $(r=0,354 ; p=0,0179)$, arginin $(r=0,423 ; p=0,004)$, sistatyonin $(r=0,423 ; p=0,004)$, etanolamin $(r=0,437$; $p=0,003)$, glisin $(r=0,399 ; p=0,007)$, histidin $(r=0,512 ; p<0,001)$, 3-metil histidin $(r=0,327 ; p=0,028)$, lösin $(r=0,376 ; p=0,011)$, metyonin $(r=0,585$; $p<0,001)$, ornitin $(r=0,467 ; p=0,001)$, fenilalanin $(r=0,644 ; p<0,001)$, prolin $(r=0,523 ; p<0,001)$, treonin $(r=0,371 ; p=0,012)$ arasında pozitif yönlü orta düzeyde, GKS skoru ile beta alanin ( $r=-0,390 ; p=0,008)$, etanolamin $(r=-0,364 ; p=0,014)$, glisin $(r=-0,360 ; p=0,015)$, ornitin $(r=-0,510$; $p=0,000)$, fenilalanin ( $r=-0,433 ; p=0,003)$ arasında negatif yönlü orta düzeyde anlamlı korelasyon saptadık.

Sonuç: Bu çalışmada risk skoru yüksek ve prognozu kötü olan hastalarda metiyonin, ornitin, fenilalanin, beta-alanin, sistin, 3-metil histidin, prolin, alanin, glisin, histidin düzeylerinin yüksek olduğunu saptadık. Sonuçlarımız, kritik hastalarda bozulmuş enerji metabolizması ile kas proteini yıkımı arasında yakın ve anlamlı bir ilişki olduğunu düşündürtmektedir.

Anahtar Kelimeler: Amino asitler, yoğun bakım üniteleri, prognoz, risk faktörleri, APACHE, basitleştirilmiş akut fizyoloji skoru, organ disfonksiyon skorları

\section{INTRODUCTION}

The metabolic conditions of critical illnesses in the intensive care units (ICU) are quite complex (1). These unitary patients have an increased catabolic state, resting energy expenditure, and metabolic activity, thus these patients should be considered as a privileged group $(2,3)$. This pathological process involved many mechanisms, which result in muscle degeneration and impaired immune response if not treated immediately may delay recovery and cause increased mortality. Therefore, detecting these metabolic disorders is important in the clinical management of these patients. The simplified acute physiology score II (SAPS II), acute physiology and chronic health evaluation II (APACHE II), sequential organ failure assessment (SOFA), multiple organ dysfunction score (MODS), and glasgow coma scale (GCS) scoring systems are used to determine the prognosis and disease severity in these patients (4).
The plasma levels of most amino acids are thought to be altered in conditions such as sepsis (5). Therefore, information about the important amino acid levels in patients who are critically ill and the therapeutic approach and its timing is insufficient. This present study aimed to investigate the relationship between prognostic scoring systems, such as SAPS II, APACHE II, MODS, SOFA, and GKS and quantitative amino acid levels, which were used in many scientific fields in recent years.

\section{METHODS}

This study was designed as a cross-sectional study and was approved by the local Ethics Committee of University Of Health Sciences Turkey, Ümraniye Training and Research Hospital (date: 17.01.2018; number: B.10.1.TKH.4.34.H.GP.0.01/7) and was conducted following the principles of the Declaration of Helsinki. Written 
informed consent was obtained from all participants/ relatives. As a result of power analysis, 45 patients were included in the study.

Patients over 45 years of age, who were admitted to our general ICU, did not receive parenteral nutrition support in the first $24 \mathrm{~h}$ of admission, had normal liver and kidney functions, and without additional diagnoses of chronic disease were included in the study, regardless of gender. Patients under 45 years old, receiving parenteral nutrition support in the first $24 \mathrm{~h}$ of intensive care admission, with diabetes mellitus, chronic liver and kidney failure, chronic infection, neutropenia ( $\leq 500$ neutrophils $/ \mathrm{mm}^{3}$ ), and a history of malignancy were excluded from the study. A detailed medical history was taken from all patients and their relatives, and their physical examinations were performed. Biochemical blood tests, hemogram, arterial blood gas, and serum amino acid levels were analyzed. Blood sampling was performed between 08:00 and 10:00 $\mathrm{h}$ and taken within the first $48 \mathrm{~h}$ of intensive care admission. SOFA, MODS, SAPS II, APACHE II, and GCS scores of patients were calculated.

\section{Metabolic Parameters}

Plasma glucose was measured by the enzymatic test method; albumin, aspartate transaminase, and alanine transaminase by enzymatic colorimetric test (Hitachi 747 auto analyzer, German); C-reactive protein by immunoassay; iron-binding capacity, iron, total protein, blood urea nitrogen, and uric acid by spectrophotometer; creatinine by Jaffe' method; bilirubins by diazo method; sedimentation by the Westergren standard method; ferritin by immunechemiluminescence; sodium, and potassium level with ion-selective electrode analysis using Architect plus device. Hemogram parameters were measured by the electrical impedance method using the Mindray BC 6800 device. Blood gas measurements were measured using the ABL800 FLEX device.

\section{Evaluation of Serum Amino Acid Levels}

Serum amino acids (alanine, beta-alanine, alpha aminoadipic acid, alpha aminobutyric acid, gamma-aminobutyric acid, arginine, asparagine, aspartic acid, citrulline, cystathionine, Sistine, homocysteine, ethanolamine, glutamine, glutamic acid, glycine, histidine, 1-methyl histidine, 3-methyl histidine, leucine, isoleucine, lysine, hydroxylysine, methionine, ornithine, phenylalanine, proline, hydroxyproline, serine, taurine, threonine, tryptophan, tyrosine, and valine) were separated by liquid chromatography technique using the Shimadzu Prominence UFLC system. The AB Sciex OTRAP 5500 tandem mass spectrometer was used for measurements. The separation of amino acids was carried out at a temperature of $50{ }^{\circ} \mathrm{C}$. The amino acid was determined in plasma using the ARCHITECT i2000SR immunoassay analyzer, Abbott Diagnostics, Abbot Park device.

\section{Calculation of Risk Scores}

The patients' APACHE II, MODS, SOFA, and SAPS II scores were calculated using a calculator with parameters such as heart rate, mean arterial pressure, respiratory rate, rectal temperature level, $\mathrm{PaO}_{2} / \mathrm{Fio}_{2}$, arterial $\mathrm{pH}$, bicarbonate level, sodium level, potassium level, serum creatinine level, hematocrit, leukocyte count, hypotension status, bilirubin level, platelet count, type of hospital admission, presence of chronic disease, age, serum creatinine/blood urea nitrogen ratio, systolic blood pressure, hourly urine output, and GCS score (6-9). The GCS was calculated using the eye-opening, motor, and verbal responses (10). Patients were grouped according to the APACHE II risk score as $<25$ points: Low risk and $\geq 25$ points: High-risk; the SAPS II score as $<41$ points: Low risk and $\geq 4$ : High-risk; the MODS score as $<13$ points: Low risk and $\geq 13$ points: High-risk; the SOFA score as $<13$ points: low risk and $\geq 13$ points: High-risk; and the GCS score as < 8 points: high-risk, 8-13 points: medium risk, and $>13$ low risks.

\section{Statistical Analysis}

Continuous variables were described using the mean, standard deviation, minimum, maximum, and median. Spearman's rho coefficient (for two non-normally distributed continuous variables) and Pearson's correlation coefficient (for two normally distributed continuous variables) were used in the correlation analyses. The comparison of continuous variables belonging to more than two groups that did not fit the normal distribution was made with the Kruskal-Wallis test. The Mann-Whitney $U$ test (for two independent and normally distributed variables) and Student's t-test (two independent and normally distributed continuous variables) was used for comparison between groups. Sensitivity and specificity calculations were made to examine the strength of the applied diagnostic tests. Statistical significance was accepted as a p-value of 0.05. MedCalc Statistics program 12.7.7 was used for statistical analysis (MedCalc Software bvba, Ostend, Belgium; http=//www.medcalc.org; 2013).

\section{RESULTS}

This study was carried out on 45 patients, wherein 23 were females and 22 were males. The mean age of the patients was $74 \pm 11$ years and the mean length of ICU stay was $18 \pm 18$ days. ICU discharge was recorded in $62.2 \%$ of the patients, whereas $37.8 \%$ died. The risk scores and quantitative amino acid levels of patients are summarized in Table 1. 
Table 1. The risk scores and quantitative amino acid levels of the patients $(n=45)$

\begin{tabular}{|c|c|c|c|c|c|}
\hline & Average & SD & Median & Min & Max \\
\hline APACHE II & 19 & 8 & 20 & 4 & 35 \\
\hline SAPS II & 51 & 16 & 50 & 21 & 94 \\
\hline MODS & 6 & 3 & 5 & 1 & 18 \\
\hline SOFA & 6 & 3 & 6 & 0 & 15 \\
\hline GCS & 10 & 5 & 10 & 3 & 18 \\
\hline Alanin $(\mu \mathrm{mol} / \mathrm{L})$ & 301,54 & 171,26 & 245,07 & 112 & 924,8 \\
\hline Beta alanin $(\mu \mathrm{mol} / \mathrm{L})$ & 1.6 & 0,9 & 1.2 & 1 & 5.7 \\
\hline Alpha aminoadipic acid ( $\mu \mathrm{mol} / \mathrm{L})$ & 2,864 & 2,744 & 1 & 1 & 10.2 \\
\hline Alpha aminobutyric acid ( $\mu \mathrm{mol} / \mathrm{L})$ & 18.46 & 13.92 & 14.3 & 5.3 & 71.2 \\
\hline Gama aminobutyric acid ( $\mu \mathrm{mol} / \mathrm{L})$ & 129 & 114 & 110 & 10 & 620 \\
\hline Arginine $(\mu \mathrm{mol} / \mathrm{L})$ & 50.52 & 36.78 & 40 & 9 & 192,63 \\
\hline Asparagin ( $\mu \mathrm{mol} / \mathrm{L})$ & 36.62 & 15.84 & 37.72 & 13.2 & 89 \\
\hline Aspartic acid ( $\mu \mathrm{mol} / \mathrm{L})$ & 8,472 & 6,666 & 7.1 & 1.2 & 37.92 \\
\hline Citruline $(\mu \mathrm{mol} / \mathrm{L})$ & 25,336 & 12,797 & 24.8 & 3,198 & 52 \\
\hline Cystathionine ( $\mu \mathrm{mol} / \mathrm{L})$ & 14,117 & 34.88 & 3.1 & 0.27 & 198,96 \\
\hline Sistine $(\mu \mathrm{mol} / \mathrm{L})$ & 24,156 & 11,102 & 23.72 & 6.19 & 56.46 \\
\hline Homocystine ( $\mu \mathrm{mol} / \mathrm{L})$ & 1,926 & 2,263 & 1 & 0 & 10.52 \\
\hline Ethanolamine $(\mu \mathrm{mol} / \mathrm{L})$ & 10,096 & 8,839 & 6 & 2 & 35.4 \\
\hline Glutamine ( $\mu \mathrm{mol} / \mathrm{L})$ & 440,09 & 157,42 & 410,6 & 237 & 898,61 \\
\hline Glutamic acid ( $\mu \mathrm{mol} / \mathrm{L})$ & 70.36 & 32.63 & 62 & 26.02 & 163,78 \\
\hline Glycine ( $\mu \mathrm{mol} / \mathrm{L})$ & 207,29 & 114,25 & 179,5 & 20.3 & 619 \\
\hline Histidine $(\mu \mathrm{mol} / \mathrm{L})$ & 70.59 & 24.29 & 65.5 & 40 & 128 \\
\hline 1-Methyl histidine ( $\mu \mathrm{mol} / \mathrm{L})$ & 8,253 & 11,873 & 4,516 & 0.1 & 63.19 \\
\hline 3-Methyl histidine $(\mu \mathrm{mol} / \mathrm{L})$ & 16,405 & 11,032 & 13.44 & 0.61 & 44.5 \\
\hline Leucine ( $\mu \mathrm{mol} / \mathrm{L})$ & 115,16 & 43.22 & 102,7 & 30 & 227,39 \\
\hline Isolocine ( $\mu \mathrm{mol} / \mathrm{L})$ & 69.25 & 31.3 & 64 & 15 & 171,47 \\
\hline Lysine ( $\mu \mathrm{mol} / \mathrm{L})$ & 171,18 & 47.47 & 165 & 83 & 289,36 \\
\hline Hydroxylyzine $(\mu \mathrm{mol} / \mathrm{L})$ & 4,879 & 7,255 & 1.06 & 0.23 & 28.51 \\
\hline Methionine $(\mu \mathrm{mol} / \mathrm{L})$ & 29.35 & 16.83 & 23.8 & 8.9 & 81.06 \\
\hline Ornithine ( $\mu \mathrm{mol} / \mathrm{L})$ & 107,11 & 43.59 & 95.25 & 39 & 241 \\
\hline Fenilalanine $(\mu \mathrm{mol} / \mathrm{L})$ & 109,51 & 56.87 & 96 & 40 & 372 \\
\hline Proline $(\mu \mathrm{mol} / \mathrm{L})$ & 208,69 & 86.76 & 178,23 & 84 & 538 \\
\hline Hydroxyproline ( $\mu \mathrm{mol} / \mathrm{L})$ & 13,219 & 11,353 & 9.215 & 1.45 & 44.79 \\
\hline Serine $(\mu \mathrm{mol} / \mathrm{L})$ & 100,83 & 48.07 & 91.09 & 47 & 316,64 \\
\hline Taurine $(\mu \mathrm{mol} / \mathrm{L})$ & 59.06 & 58.13 & 33 & 6 & 313,76 \\
\hline Threonine $(\mu \mathrm{mol} / \mathrm{L})$ & 122,04 & 50.29 & 110 & 54 & 259,2 \\
\hline Triptophan $(\mu \mathrm{mol} / \mathrm{L})$ & 35.81 & 18,811 & 32 & 6,639 & 106,4 \\
\hline Tyrosin $(\mu \mathrm{mol} / \mathrm{L})$ & 56.85 & 1852 & 53.66 & 14 & 94.11 \\
\hline Valine ( $\mu \mathrm{mol} / \mathrm{L})$ & 264,93 & 359,23 & 203.2 & 66 & 2.587 \\
\hline
\end{tabular}

SD: Standard deviation, Min: Minimum, Max: Maximum, APACHE II: The acute physiology and chronic health evaluation II, SAPS II: Simplified acute physiology score, MODS: Multiple organ dysfunction score, SOFA: Sequential organ failure assessment, GCS: Glasgow coma scale 
The correlation analysis between risk scores and quantitative amino acid levels found that as the risk scores of patients increased, the levels of some amino acids also increased. A moderate positive correlation was found between the APACHE II score and beta-alanine, citrulline, ethanolamine, histidine, 3-methyl histidine, ornithine, and phenylalanine; a weak statistically significant positive correlation between the APACHE II score and cystathionine; a moderate positive correlation between the SAPS I| score and beta-alanine, cystathionine, ethanolamine, 3-methyl histidine, ornithine, and phenylalanine; a weak statistically significant correlation between the SAPS II score and glycine, and valine; a moderately positive correlation between the MODS score and alanine, beta-alanine, cystathionine, ethanolamine, histidine, 3-methyl histidine, methionine, ornithine, phenylalanine, and proline; a weak positive correlation between MODS score and arginine and leucine; a moderate positive correlation between SOFA score and alanine, betaalanine, arginine, cystathionine, ethanolamine, glycine, histidine, 3-methyl histidine, leucine, methionine, ornithine, phenylalanine, proline, and threonine; a weak positive and statistically significant correlation between SOFA score and 3-methyl histidine, lysine, and serine; and a moderately statistically significant negative correlation between the GCS score and beta-alanine, ethanolamine, glycine, ornithine, phenylalanine, and proline (Table 2).

The regression analysis between quantitative amino acid levels and risk scores found that a 1-unit change in citrulline increased the APACHE II score by 0.169 times, a 1-unit change in ethanolamine increased the APACHE \| score by 0.193 times, and a 1-unit change in 3-methyl histidine increased the APACHE II score by 0.225 times. However, it could not be interpreted due to the multicollinearity problem between other risk scores and amino acid levels.

Methionine, ornithine, and phenylalanine levels were found to be higher in the high-risk group according to the APACHE II risk score ( $p=0.011, p=0.019$, and $p<0.001$, respectively). Beta-alanine, cystine, 3-methyl histidine, phenylalanine, and proline levels were significantly higher in the high-risk group according to the SAPS II score ( $p=0.038, p=0.038, p=0.024$, $p=0.011, p=0.027$, respectively). In addition, alanine, betaalanine, phenylalanine, glycine, histidine, methionine, and ornithine levels were higher in the high-risk group than in the low risk group according to the GCS score $(p=0.031$, $p=0.035, p=0.006, p=0.005, p=0.007 p=0.044$, and $p=0.007$, respectively). When the patients were divided into highrisk and low risk according to MODS and SOFA scores, comparison could not be made because the sample size in both groups was insufficient.

\section{DISCUSSION}

This study revealed a significant correlation between mortality and morbidity risk scores and beta-alanine, methionine, ornithine, phenylalanine, cystine, 3-methyl histidine, proline, alanine, glycine, histidine, and cystathionine levels. Present results suggested a close and significant relationship between impaired energy metabolism and muscle protein breakdown in patients who are critically ill.

Amino acids present in serum are metabolites that are released during protein catabolism. Serum amino acid levels are stable in healthy individuals but may change in catabolic states or metabolic diseases. Plasma amino acid levels decrease in cases of nephrotic syndrome, rheumatoid arthritis, and adrenocortical hyperfunction, but increase in malabsorption, diabetes, chronic kidney and liver failure, and septic shock (11). This study provides a theoretical basis to predict mortality and serum amino acid levels of patients in the ICUs. The comprehensive study of serum amino acid levels and risk scores made this study valuable.

ICUs are areas where critically ill and high-risk patients are followed with invasive and non-invasive methods, lifesupport functions, and intensive treatment using the latest technology (12). The metabolic disorders of patients in these units are quite complex (13). Catabolic events are higher than anabolic events in these patients due to increased cytokine levels and hyperactivity of some inflammatory mediators (14). Many factors affect the prognosis of patients in these units. The patient's current physiological reserve, type of disease, and treatment response are the most important factors. The clinical status of patients in the ICU can instantaneously change, thus their vital activities are mostly supported by external devices and drugs, and their lives continue with high-level treatment and care practice. Prognostic mortality and morbidity calculations related to organ failure are extremely important in this patient group (15). These scores, which are used to determine the severity of the disease, are widely used in the ICUs to measure the degree of organ dysfunction, determine the severity of the disease, and predict the treatment response (15).

Amino acid levels, which are the building blocks of proteins, change in critical diseases (16). Sepsis is an important catabolic process that causes a peripheral energy deficit resulting from the breakdown of muscle proteins, partially increased lean body mass, and increased oxidation of amino acids, primarily, branched-chain amino acids (17). Correlations were shown between the clinical status of critically ill patients, such as sepsis, and certain laboratory 
Uçak Basat et al. Amino Acids and Prognostic Risk Scores

Table 2. Analysis of correlation between risk scores and quantitative amino acids

\begin{tabular}{|c|c|c|c|c|c|c|}
\hline & & APACHE II & SAPS II & MODS & SOFA & GCS \\
\hline \multirow[t]{2}{*}{ Alanine ( $\mu \mathrm{mol} / \mathrm{L})$} & $\mathbf{r}$ & 0.248 & 0.275 & $0.34^{\star *}$ & $0.547^{\star \star}$ & -0.267 \\
\hline & $\mathbf{p}$ & 0.1 & 0.067 & 0.022 & $<0.001$ & 0.077 \\
\hline \multirow[t]{2}{*}{ Beta-alanine $(\mu \mathrm{mol} / \mathrm{L})$} & $\mathbf{r}$ & $0.466^{* *}$ & $0.403^{\star *}$ & $0.407^{\star \star}$ & $0.354^{\star *}$ & $-0.39^{\star *}$ \\
\hline & $\mathbf{p}$ & 0.001 & 0.006 & 0.006 & 0.017 & 0.008 \\
\hline \multirow[t]{2}{*}{ Alpha aminoadipic acid ( $\mu \mathrm{mol} / \mathrm{L})$} & $\mathbf{r}$ & 0.074 & -0.058 & 0.134 & 0.179 & -0.033 \\
\hline & $\mathbf{p}$ & 0.627 & 0.705 & 0.381 & 0.24 & 0.83 \\
\hline \multirow[t]{2}{*}{ Alpha aminobutyric acid ( $\mu \mathrm{mol} / \mathrm{L})$} & $\mathbf{r}$ & 0.077 & 0.017 & 0.162 & 0.231 & -0.072 \\
\hline & $\mathbf{p}$ & 0.613 & 0.914 & 0.288 & 0.126 & 0.638 \\
\hline \multirow[t]{2}{*}{ Gamma-aminobutyric acid ( $\mu \mathrm{mol} / \mathrm{L})$} & $\mathbf{r}$ & 0.196 & 0.152 & 0.047 & 0.063 & -0.154 \\
\hline & $\mathbf{p}$ & 0.198 & 0.318 & 0.762 & 0.681 & 0.312 \\
\hline \multirow[t]{2}{*}{ Arginine $(\mu \mathrm{mol} / \mathrm{L})$} & $\mathbf{r}$ & 0.103 & 0.089 & $0.297^{\star *}$ & $0.423^{\star *}$ & -0.004 \\
\hline & $\mathbf{p}$ & 0.499 & 0.563 & 0.047 & 0.004 & 0.98 \\
\hline \multirow[t]{2}{*}{ Asparagine $(\mu \mathrm{mol} / \mathrm{L})$} & $\mathbf{r}$ & 0.032 & -0.074 & -0.169 & -0.055 & 0.154 \\
\hline & $\mathbf{p}$ & 0.834 & 0.629 & 0.268 & 0.722 & 0.312 \\
\hline \multirow[t]{2}{*}{ Aspartic acid ( $\mu \mathrm{mol} / \mathrm{L})$} & $\mathbf{r}$ & 0.072 & -0.182 & 0.047 & 0.104 & 0.08 \\
\hline & $\mathbf{p}$ & 0.638 & 0.232 & 0.761 & 0.498 & 0.603 \\
\hline \multirow[t]{2}{*}{ Citrulline $(\mu \mathrm{mol} / \mathrm{L})$} & $\mathbf{r}$ & $0.394^{*}$ & $0.152^{*}$ & 0.219 & $0.220^{*}$ & -0.2 \\
\hline & $\mathbf{p}$ & 0.007 & 0.319 & 0.148 & 0.147 & 0.189 \\
\hline \multirow[t]{2}{*}{ Cystathionine ( $\mu \mathrm{mol} / \mathrm{L})$} & $\mathbf{r}$ & $0.315^{\star \star}$ & $0.341^{* *}$ & $0.352^{\star *}$ & $0.423^{\star *}$ & -0.227 \\
\hline & $\mathbf{p}$ & 0.035 & 0.022 & 0.018 & 0.004 & 0.134 \\
\hline \multirow[t]{2}{*}{ Sistine ( $\mu \mathrm{mol} / \mathrm{L})$} & $\mathbf{r}$ & $0.216^{*}$ & $0.110^{*}$ & 0.182 & $0.124^{*}$ & 0.026 \\
\hline & $\mathbf{p}$ & 0.154 & 0.473 & 0.233 & 0.415 & 0.867 \\
\hline \multirow[t]{2}{*}{ Homocysteine $(\mu \mathrm{mol} / \mathrm{L})$} & $\mathbf{r}$ & -0.013 & -0.093 & -0.2 & -0.087 & 0.107 \\
\hline & $\mathbf{p}$ & 0.934 & 0.542 & 0.188 & 0.571 & 0.484 \\
\hline \multirow[t]{2}{*}{ Ethanolamine $(\mu \mathrm{mol} / \mathrm{L})$} & $\mathbf{r}$ & $0.366^{\star *}$ & $0.356^{\star *}$ & $0.358^{\star *}$ & $0.437^{\star *}$ & $-0.364^{\star \star}$ \\
\hline & $\mathbf{p}$ & 0.013 & 0.017 & 0.016 & 0.003 & 0.014 \\
\hline \multirow[t]{2}{*}{ Glutamine $(\mu \mathrm{mol} / \mathrm{L})$} & $\mathbf{r}$ & 0.184 & 0.045 & 0.076 & 0.216 & -0.078 \\
\hline & $\mathbf{p}$ & 0.227 & 0.768 & 0.621 & 0.153 & 0.613 \\
\hline \multirow[t]{2}{*}{ Glutamic acid $(\mu \mathrm{mol} / \mathrm{L})$} & $\mathbf{r}$ & 0.235 & 0.208 & 0.064 & 0.027 & -0.194 \\
\hline & $\mathbf{p}$ & 0.121 & 0.171 & 0.674 & 0.859 & 0.201 \\
\hline \multirow[t]{2}{*}{ Glycine ( $\mu \mathrm{mol} / \mathrm{L})$} & $\mathbf{r}$ & 0.187 & $0.339^{\star *}$ & 0.207 & $0.399^{* \star}$ & $-0.36^{\star *}$ \\
\hline & $\mathbf{p}$ & 0.218 & 0.023 & 0.172 & 0.007 & 0.015 \\
\hline \multirow[t]{2}{*}{ Histidine $(\mu \mathrm{mol} / \mathrm{L})$} & $\mathbf{r}$ & $0.353^{\star \star}$ & 0.255 & $0.495^{\star *}$ & $0.512^{\star *}$ & -0.282 \\
\hline & $\mathbf{p}$ & 0.017 & 0.091 & 0.001 & $<0.001$ & 0.061 \\
\hline \multirow[t]{2}{*}{ 1-Methyl histidine ( $\mu \mathrm{mol} / \mathrm{L})$} & $\mathbf{r}$ & -0.169 & -0.146 & -0.05 & -0.091 & 0.058 \\
\hline & $p$ & 0.268 & 0.34 & 0.745 & 0.554 & 0.703 \\
\hline \multirow[t]{2}{*}{ 3-Methyl histidine ( $\mu \mathrm{mol} / \mathrm{L})$} & $\mathbf{r}$ & $0.45^{\star *}$ & $0.402^{\star \star}$ & $0.407^{\star \star}$ & $0.327^{* *}$ & -0.232 \\
\hline & $\mathbf{p}$ & 0.002 & 0.006 & 0.006 & 0.028 & 0.126 \\
\hline \multirow[t]{2}{*}{ Leucine $(\mu \mathrm{mol} / \mathrm{L})$} & $\mathbf{r}$ & $0.200^{*}$ & $0.120^{\star}$ & $0.33^{\star *}$ & $0.376^{*}$ & -0.171 \\
\hline & $\mathbf{p}$ & 0.187 & 0.433 & 0.027 & 0.011 & 0.26 \\
\hline \multirow[t]{2}{*}{ Isoleucine ( $\mu \mathrm{mol} / \mathrm{L})$} & $\mathbf{r}$ & $0.118^{*}$ & $0.011^{*}$ & 0.225 & $0.303^{\star}$ & 0.015 \\
\hline & $\mathbf{p}$ & 0.464 & 0.947 & 0.158 & 0.054 & 0.927 \\
\hline \multirow[t]{2}{*}{ Lysine ( $\mu \mathrm{mol} / \mathrm{L})$} & $r$ & 0.149 & 0.095 & 0.204 & $0.336^{\star *}$ & -0.085 \\
\hline & $\mathbf{p}$ & 0.329 & 0.534 & 0.178 & 0.024 & 0.579 \\
\hline
\end{tabular}




\section{Table 2. Contunued}

\begin{tabular}{|c|c|c|c|c|c|c|}
\hline \multirow[t]{2}{*}{ Hydroxylysine ( $\mu \mathrm{mol} / \mathrm{L})$} & $\mathbf{r}$ & 0.16 & 0.051 & 0.2 & 0.252 & -0.093 \\
\hline & $\mathbf{p}$ & 0.293 & 0.738 & 0.188 & 0.095 & 0.542 \\
\hline \multirow[t]{2}{*}{ Methionine $(\mu \mathrm{mol} / \mathrm{L})$} & $\mathbf{r}$ & 0.27 & 0.268 & $0.462^{\star *}$ & $0.585^{\star \star}$ & -0.263 \\
\hline & $\mathbf{p}$ & 0.073 & 0.075 & 0.001 & $<0.001$ & 0.081 \\
\hline \multirow[t]{2}{*}{ Ornithine ( $\mu \mathrm{mol} / \mathrm{L})$} & $\mathbf{r}$ & $0.445^{\star \star}$ & $0.349^{\star *}$ & $0.36^{\star *}$ & $0.467^{\star \star}$ & $-0.51^{\star *}$ \\
\hline & $\mathbf{p}$ & 0.002 & 0.019 & 0.015 & 0.001 & 0 \\
\hline \multirow[t]{2}{*}{ Phenylalanine ( $\mu \mathrm{mol} / \mathrm{L})$} & $\mathbf{r}$ & $0.548^{\star \star}$ & $0.525^{\star *}$ & $0.621^{\star *}$ & $0.644^{\star *}$ & $-0.433^{\star \star}$ \\
\hline & $\mathbf{p}$ & $<0.001$ & $<0.001$ & $<0.001$ & $<0.001$ & 0.003 \\
\hline \multirow[t]{2}{*}{ Proline ( $\mu \mathrm{mol} / \mathrm{L})$} & $\mathbf{r}$ & 0.283 & 0.277 & $0.445^{\star *}$ & $0.523^{* *}$ & -0.25 \\
\hline & $\mathbf{p}$ & 0.06 & 0.065 & 0.002 & $<0.001$ & 0.097 \\
\hline \multirow[t]{2}{*}{ Hydroxyproline ( $\mu \mathrm{mol} / \mathrm{L}$ ) } & $\mathbf{r}$ & -0.135 & -0.092 & -0.227 & 0.042 & 0.191 \\
\hline & $\mathbf{p}$ & 0.376 & 0.547 & 0.133 & 0.784 & 0.209 \\
\hline \multirow[t]{2}{*}{ Serine $(\mu \mathrm{mol} / \mathrm{L})$} & $\mathbf{r}$ & -0.085 & -0.088 & 0.06 & $0.335^{\star \star}$ & -0.003 \\
\hline & $\mathbf{p}$ & 0.581 & 0.565 & 0.697 & 0.025 & 0.984 \\
\hline \multirow[t]{2}{*}{ Taurine ( $\mu \mathrm{mol} / \mathrm{L})$} & $r$ & 0.241 & 0.079 & 0.174 & 0.074 & -0.066 \\
\hline & $\mathbf{p}$ & 0.111 & 0.608 & 0.253 & 0.629 & 0.668 \\
\hline \multirow[t]{2}{*}{ Threonine $(\mu \mathrm{mol} / \mathrm{L})$} & $\mathbf{r}$ & -0.005 & 0.004 & 0.118 & $0.371^{\star \star}$ & -0.058 \\
\hline & $\mathbf{p}$ & 0.972 & 0.979 & 0.44 & 0.012 & 0.703 \\
\hline \multirow[t]{2}{*}{ Tryptophan $(\mu \mathrm{mol} / \mathrm{L})$} & $\mathbf{r}$ & 0.018 & 0.101 & 0.179 & 0.257 & -0.153 \\
\hline & $\mathbf{p}$ & 0.905 & 0.51 & 0.239 & 0.088 & 0.317 \\
\hline \multirow[t]{2}{*}{ Tyrosin $(\mu \mathrm{mol} / \mathrm{L})$} & $\mathbf{r}$ & $-0.035^{\star}$ & $0.066^{*}$ & -0.079 & $0.115^{*}$ & 0.051 \\
\hline & $\mathbf{p}$ & 0.818 & 0.665 & 0.607 & 0.451 & 0.741 \\
\hline \multirow[t]{2}{*}{ Valine ( $\mu \mathrm{mol} / \mathrm{L})$} & $\mathbf{r}$ & $0.119^{*}$ & $0.319^{*}$ & 0.278 & $0.228^{*}$ & -0.154 \\
\hline & $\mathbf{p}$ & 0.435 & 0.033 & 0.065 & 0.133 & 0.314 \\
\hline
\end{tabular}

**Spearman's rho p, *Pearson p APACHE II: The acute physiology and chronic health evaluation II, SAPS II: Simplified acute physiology score, MODS: Multiple organ dysfunction score, SOFA: Sequential organ failure assessment, GCS: Glasgow coma scale

values (18). However, very few studies showed the relationship between serum amino acid values and disease follow-up. Freund et al. (19) revealed that some amino acid levels can be used as a marker of disease severity and prognosis. Conversely, a study by Vente et al. (5) suggested that amino acid levels show nonspecific trends in critically ill patients, and therefore, may not be useful in predicting disease severity. However, the current study revealed that some amino acids were associated with prognosis.

A study determined that the level of sulfur-containing amino acids, especially taurine, was lower in patients with severe sepsis, and serum taurine level and SOFA and APACHE II scores showed a weak negative correlation (20). However, our study revealed that taurine level was not associated with any risk score. Again, in the same study, sulfur-containing amino acids, such as methionine, cysteine, and cystine, were found to be significantly lower in patients with severe sepsis (20). Our study revealed that cysteine was correlated with APACHE II, SAPS II, MODS, and SOFA, and methionine was correlated with MODS and SOFA scores. In the same study, histidine, citrulline, proline, ornithine, tryptophan, threonine, tyrosine, isoleucine, valine, lysine, asparagine, cystathionine, and leucine levels were found to be lower in patients with sepsis (20). However, our study revealed that these amino acid levels were higher in patients who are critically ill.

Citrulline was shown to improve vascular function, lower blood pressure, and increase peripheral blood flow by increasing nitric oxide synthesis (21). The present study revealed that citrulline levels were not low in patients with high-risk scores. This significant effect is explained by the increased peripheral oxygenation and regulation of the immune system. Low levels of branched-chain amino acids, such as isoleucine, leucine, and valine, were shown to promote protein catabolism and decrease muscle protein synthesis (22). However, our study did not find a significant relationship between these amino acid levels and prognostic risk scores.

A study by Beale et al. (23) found a correlation between sulfur-containing amino acid levels and SOFA score in patients with sepsis and emphasized that the levels of 
these amino acids are low in patients with high-risk scores and amino acids- rich diet is important in the nutritional therapy of these patients. However, our study revealed no association between cystine, a sulfur-containing amino acid, and any risk score. A positive correlation was found between methionine, another sulfur-containing amino acid, and MODS and SOFA scores in our study. Another study detected higher levels of alanine and branched-chain amino acids in patients recovering from sepsis (24). However our study found no correlation between the alanine or other branched-chain amino acids and risk scores.

Ornithine is an essential amino acid involved in the urea cycle (25) and is known to positively affect liver functions and help detoxify harmful substances. In addition, ornithine positively affects wound healing and strengthens the immune system (25). Ornithine is metabolized to L-arginine (26). L-arginine stimulates the release of growth hormones from the pituitary. In catabolic conditions, the plasma L-arginine level is affected (27). The present study found that ornithine levels increased in patients who are critically ill with poor prognostic risk scores. This result was in parallel with the data in the literature.

\section{Study Limitations}

The present study had some limitations. First, our study was a cross-sectional study. Therefore, a causal relationship could not be established between prognostic and organ failure scoring systems and serum amino acid levels. Second, this study was designed as a single-center study, thus our results may not be valid for all patients admitted to the ICU. Third, serum amino acid analysis and risk score calculations were evaluated at a single time point. Despite all these limitations, to the best of our knowledge, there is no such extensive study on this subject in the literature, thus the present study is valuable.

\section{CONCLUSION}

The present study is a guide for the prognosis and clinical treatment of patients who are critically ill in the ICUs. The study found that beta-alanine, ornithine, phenylalanine, ethanolamine, cystathionine, and 3 methyl histidine were correlated with prognostic risk scores in patients who are critically ill. Therefore, we believe that these amino acids can be used as markers to show the prognosis and severity of metabolic disorders of patients in the ICU.

\section{ETHICS}

Ethics Committee Approval: This study was designed as a cross-sectional study and was approved by the Local
Ethics Committee of University of Health Sciences Turkey, Ümraniye Training and Research Hospital (date: 17.01.2018; number: B.10.1.TKH.4.34.H.GP.0.01/7) and was conducted following the principles of the Declaration of Helsinki.

Informed Consent: Written informed consent was obtained from all participants/relatives.

\section{Authorship Contributions}

Surgical and Medical Practices: S.U.B., R.S., K.Ö., Concept: S.U.B., R.S., O.B., Design: S.U.B., R.S., A.D., K.Ö., Data Collection or Processing: R.S., P.E., Analysis or Interpretation: A.B., P.E., Literature Search: R.S., A.D., Writing: R.S., O.B., A.B., K.Ö.

Conflict of Interest: No conflict of interest was declared by the authors.

Financial Disclosure: The authors declared that this study received no financial support.

\section{REFERENCES}

1. Mickiewicz B, Tam P, Jenne CN, Leger C, Wong J, Winston BW, et al. Integration of metabolic and inflammatory mediator profiles as a potential prognostic approach for septic shock in the intensive care unit. Crit Care 2015;19:11.

2. Levy MM, Artigas A, Phillips GS, Rhodes A, Beale R, Osborn T, et al. Outcomes of the Surviving Sepsis Campaign in intensive care units in the USA and Europe: a prospective cohort study. Lancet Infect Dis 2012;12:919-24.

3. Michie HR. Metabolism of sepsis and multiple organ failure. World J Surg 1996;20:460-4.

4. Rosenberg AL. Recent innovations in intensive care unit riskprediction models. Curr Opin Crit Care 2002;8:321-30.

5. Vente JP, von Meyenfeldt MF, van Eijk HM, van Berlo CL, Gouma DJ, van der Linden CJ, et al. Plasma-amino acid profiles in sepsis and stress. Ann Surg 1989;209:57-62.

6. APACHE II Score Estimates ICU mortality. MDCalc (02005-2021 Available from: URL: https://www.mdcalc.com/apache-ii-score.

7. Sequential Organ Failure Assessment (SOFA) Score Predicts ICU mortality based on lab results and clinical data. MDCalc (020052021 Available from: URL:https://www.mdcalc.com/sequentialorgan-failure-assessment-sofa-score.

8. Multiple Organ Dysfunction Score (MODS) @ 2021 Merck Sharp \& Dohme Corp., a subsidiary of Merck \& Co., Inc., Kenilworth, NJ, USA Available from: https://www.merckmanuals.com/professional/ multimedia/clinical-calculator/clinicalcalculator_en_v48814872.

9. Simplified Acute Physiology Score (SAPS) II Estimates mortality in ICU patients, comparable to APACHE II. MDCalc (02005-2021 Available from: URL:https://www.mdcalc.com/simplified-acutephysiology-score-saps-ii.

10. Rowley G, Fielding K. Reliability and accuracy of the Glasgow Coma Scale with experienced and inexperienced users. Lancet 1991;337:535-8.

11. Bender DA. Amino Acid Metabolism. John Wiley \& Sons, The Atrium Southern Gate Chichester West Sussex UK 2 Jul 2012 Availablefrom:https://books.google.com.tr/books?hl=tr\&lr= \&id=CLok9jcTFVsC\&oi=fnd\&pg=PT8\&dq=Disturbances + of + amino+acid+metabolism\&ots=H6VHQTLoIL\&sig= 
dJ9SikZwKhOUHYhYqdsw0tRKJ_Q\&redir_esc=y\#v=onepage\&q =Disturbances\%20of\%20amino\%20acid\% 20metabolism\&f =false.

12. Weil MH, Tang W. From intensive care to critical care medicine: a historical perspective. Am J Respir Crit Care Med 2011;183:1451-3.

13. Christopher KB. Nutritional metabolomics in critical illness. Curr Opin Clin Nutr Metab Care 2018;21:121-5.

14. Faix JD. Biomarkers of sepsis. Crit Rev Clin Lab Sci 2013;50:23-36.

15. Fleig V, Brenck F, Wolff M, Weigand MA. Scoring-Systeme in der Intensivmedizin : Grundlagen, Modelle, Anwendung und Grenzen [Scoring systems in intensive care medicine: principles, models, application and limits]. Anaesthesist 2011;60:963-74.

16. Heyland DK, Weijs PJ, Coss-Bu JA, Taylor B, Kristof AS, O'Keefe GE, et al. Protein Delivery in the Intensive Care Unit: Optimal or Suboptimal? Nutr Clin Pract 2017;32(1_suppl):58S-71S.

17. Mira JC, Gentile LF, Mathias BJ, Efron PA, Brakenridge SC, Mohr AM, et al. Sepsis Pathophysiology, Chronic Critical Illness, and Persistent Inflammation-Immunosuppression and Catabolism Syndrome. Crit Care Med 2017;45:253-62.

18. Thiel SW, Rosini JM, Shannon W, Doherty JA, Micek ST, Kollef MH. Early prediction of septic shock in hospitalized patients. J Hosp Med 2010;5:19-25.

19. Freund H, Atamian S, Holroyde J, Fischer JE. Plasma amino acids as predictors of the severity and outcome of sepsis. Ann Surg 1979;190:571-6.

20. Su L, Li H, Xie A, Liu D, Rao W, Lan L, et al. Dynamic changes in amino acid concentration profiles in patients with sepsis. PLoS One 20157;10:e0121933.
21. Figueroa A, Wong A, Jaime SJ, Gonzales JU. Influence of $\mathrm{L}$-citrulline and watermelon supplementation on vascular function and exercise performance. Curr Opin Clin Nutr Metab Care 2017;20:92-8.

22. De Bandt JP, Cynober L. Therapeutic use of branched-chain amino acids in burn, trauma, and sepsis. J Nutr 2006;136(1 Suppl):308S$13 S$.

23. Beale RJ, Sherry T, Lei K, Campbell-Stephen L, McCook J, Smith $J$, et al. Early enteral supplementation with key pharmaconutrients improves Sequential Organ Failure Assessment score in critically ill patients with sepsis: outcome of a randomized, controlled, doubleblind trial. Crit Care Med 2008;36:131-44.

24. Freund HR, Ryan JA Jr, Fischer JE. Amino acid derangements in patients with sepsis: treatment with branched chain amino acid rich infusions. Ann Surg 1978;188:423-30.

25. de Oliveira LF, Navarro BV, Cerruti GV, Elbl P, Minocha R, Minocha SC, et al. Polyamine- and Amino Acid-Related Metabolism: The Roles of Arginine and Ornithine are Associated with the Embryogenic Potential. Plant Cell Physiol 2018;59:1084-98.

26. Tsuei BJ, Bernard AC, Barksdale AR, Rockich AK, Meier CF, Kearney PA. Supplemental enteral arginine is metabolized to ornithine in injured patients. J Surg Res 2005;123:17-24.

27. Kurauchi I, Shigemi K, Kabuki Y, Hamasu K, Yamane H, Aoki M, et al. Central L-ornithine, but not polyamines, induces a hypnotic effect in neonatal chicks under acute stress. Nutr Neurosci 2010;13:17-20. 